\title{
Exploration and Practice of Training International Software Engineering Talents
}

\author{
Jing Wang \\ Department of International Communication and Cooperation, Neusoft Institute, \\ Guangdong, China \\ jingyun_wj@163.com
}

Keywords: Internationalization, Software engineering, Talent training

\begin{abstract}
The development of China's software industry is in urgent need of a large number of international software talents. The internationalization of software engineering education has gradually become the main reform direction of higher engineering education. This document expounds the connotation of international software engineering talents. Taking Neusoft Institute of Guangdong as an example, the document also explains and demonstrates training mode of international software engineering talents. The research of this paper provide reference for the reform and innovation of international software engineering talent training.
\end{abstract}

\section{Introduction}

The software industry is a new and strategic industry in China. According to report of Xinhua News Agency, in 2017, the revenue of China's software industry has exceeded 5 trillion yuan, and the ability of the software industry has been significantly improved. According to China's software export development report , in 2016, China's software industry realized revenue of 4.9 trillion yuan, and the software industry realized exports of $\$ 51.9$ billion[1]. In the future, China's software export market will form a global oriented development pattern, and needs of software engineering talents will continue to grow, and the demands for talents are knowledgeable, young and high-end[2]. It is predicted that in 2017 global software service expenditure will reach \$1.1 trillion, and a new technological revolution marked by cloud computing, big data and mobile Internet, is opening up a new era of service outsourcing. The challenges and opportunities faced by the software industry in the new situation bring higher requirements for engineering talents in terms of quality and quantity. Therefore, the internationalization of software engineering education has gradually become the main reform direction of higher engineering education. Some developed countries, such as the United States, Japan and Europe, began the reform and research of the training mode of international talents in the 90s of last century[3]. Some universities in South Korea have also introduced corresponding measures to strengthen the training of high-end software talents[4].In India, the software industry started late, but its software export has ranked second in the world, which is mainly due to the establishment of a multi-level application oriented software engineering talent training mode[5]. Although the internationalization of higher education in China has begun to develop, the government attaches great importance to the training of international talents. In the outline of the national medium and long-term education development plan (2010 2020), with the theme of "expanding education opening", the whole sixteenth chapter puts forward a programmatic guideline for the internationalization of education. In recent years, a lot of Chinese universities have begun to actively integrate into the development trend of education internationalization, and constantly increase the research and input of international talent training mode. In the field of training software engineering talents, 37 national demonstrative software colleges have actively and boldly carried out the reform of talent training mode[1]. However, the international of higher education in China is still lagging behind the developed countries. Therefore, how to cultivate the international software engineering talents, the universities need to consider actual situations, put forward countermeasures and practices. 


\section{The connotation of international software engineering talents}

International software talents possess the abilities to master one more foreign language, use technology and tools in the field of software engineering to complete intercultural communication and service, own advanced knowledge and technology in the field of software engineering and know the rules of international software industry[6]. The emphasis of the training of international software engineering talents lies in "internationalization" and "engineering practice". The training of international talents is to establish the mode and system of talent training with the thinking and methods of internationalization. The engineering education attribute of software engineering is mainly to guide students to comprehensively apply the principles of computer science, mathematics, and management, draw lessons from the principles and methods of traditional engineering, and create software to achieve the purpose of improving quality and reducing cost[7]. Therefore, universities should set up a training mode for software engineering talents for the needs of software industry, emphasizing engineering and software development, design, analysis and management technologies, highlighting practical teaching methods and training students' abilities.

\section{Exploration on the training of international software engineering talents}

Under the guidance of training goals and educational ideas, the Neusoft Institute of Guangdong has boldly explored and reformed the training mode of international software engineering talents.

\subsection{Recruiting foreign students to study software engineering major}

Through cooperation with foreign admissions agencies, participating in overseas recruitment lectures, and going abroad for enrollment and publicity, Neusoft Institute of Guangdong carries out enrollment for foreign students. In 2017, more than 30 foreign students from Indonesia, Philippines, Jordan, Tanzania and Ethiopia were recruited. In the software engineering major, Chinese and foreign students study together, the courses are taught all in English. The Neusoft institute of Guangdong has also set up an overseas student office to set up full-time staff to deal with foreign students' related affairs. The increase in the number of overseas students brings different elements of culture in different countries. It has greatly promoted the formation of the institute's international atmosphere.

\subsection{Constructing of international talent training program}

Neusoft Institute of Guangdong has cooperated with different universities in the United States, Canada, Australia, Britain and India to implement " $3+1$ ", " $2+2$ ", " $3+1+1$ " joint training education programs. According to the international standard, combined with the talent demand of software industry, to cultivate students' learning ability, knowledge and technology ability, anti frustration ability, adaptation ability, innovative ability and the ability to use English as the goal, the institute has built an international software engineering curriculum system, including general knowledge courses, professional basic courses, professional core courses, elective courses and project practice courses. The foreign excellent original textbooks are adopted, covering the professional knowledge, the frontier technology and the latest achievements in the field of software engineering. With the guidance of advanced engineering education concepts, many kinds of teaching modes, such as project driven, case study and intensive practicing, are adopted. Especially in the teaching of specialized courses based on project driven, Chinese and international students as mixed as groups, guiding them to design and development of the project in accordance with the common international standards. These teaching strategies promote the communication between Chinese and foreign students, feel the way of thinking of different countries, enhance their practical abilities and teamwork abilities.

\subsection{Constructing of international faculties}

Neusoft Institute of Guangdong has always adhered to the principle of "introducing and sending out", and formed a diversified and international teaching faculties of software engineering. Neusoft 
Institute of Guangdong has established a long-term cooperative relationship with Vellore Institute of Technology(VIT) in India. From 2016, VIT sent foreign teachers to Neusoft Institute of Guangdong to teach students core specialized courses of software engineering. Up to now, 6 professors from VIT have completed 16 professional core specialized courses. All software engineering teachers of Neusoft Institute of Guangdong have the background of studying abroad. The Institute has been insisting on selecting teachers in batches to visit famous universities in the US, Canada, Singapore, India and other countries for short-term exchange visits and curriculum training, so as to enhance teachers' international teaching level.

\subsection{Promoting multicultural activities}

Each semester, the International Department of Neusoft Institute of Guangdong will receive many short-term exchange visits from Hong Kong, Macao, India, Britain, Canada and the United States. Since 2015, Neusoft Institute of Guangdong held many international culture activities each year. Especially in the 2017 "Multicultural Food Festival", four universities in Taiwan, a VIT MBA delegation and many African, Indonesia and Philippines students were actively involved. This activity has become the highlight of "2017 campus open week" and has been actively publicized by Foshan TV station. These communication activities provide students with a diversified communication environment, greatly improving students' English ability, and effectively promoting the development of Foshan's diversified culture. These activities have also been supported by Foshan government agencies, which greatly promoted the international influence of Neusoft Institute of Guangdong.

\section{Summary}

Through the exploration and practice of international talent training, Neusoft Institute of Guangdong has gained some achievements in the aspects of joint training education programs, training quality of internationalized software talents, teaching reform research, scientific research project cooperation, and mutual visits between Sino-foreign universities. These achievements have put forward the experience that can be used for reference for the reform of the training mode of international software talents. In the future, the Institute will also develop an internationalized teaching platform, taking the international discipline competition and research center as a means to cultivate the innovative ability of software engineering talents, and strengthen cooperation with enterprises, enhancing practical teaching system, so as to improve students' practical application ability.

The training of international talents in software engineering is a new topic to adapt to the development of the times and the international environment. This is also a challenge for Chinese higher education reform. To cultivate competitive international software talents, colleges and universities should extensively carry out international exchanges and cooperation, and effectively introduce and utilize high-quality educational resources abroad. Through cooperation with foreign universities, the international vision of software engineering education can be broadened and the international advanced educational concepts and teaching modes can be absorbed [8]. Chinese universities should constantly deepen the reform of education and teaching and explore talent training mode that is suitable for the actual situation of universities and majors, meet the needs of software industry development and cultivate a large number of excellent international software engineering talents for China's economic construction and social development.

\section{Acknowledgement}

This research was financially supported 2017 Innovation and Reinforcing project of Neusoft Institute of Guangdong (Grant NO. 2017-52), 2017 Higher Education Research Project of Neusoft Institute of Guangdong (Grant NO. 2017-30), Foshan Science and Technology Bureau Innovation Project (Grant NO. 2016AG100382, NO. 2016AG100792). 


\section{References}

[1] China's ministry of commerce. China's software export development report 2016. Beijing: Business press, 2016.

[2] X. H. Wang, Q. Yu. The current situation and trend of China's software export, Research and Economics and Management, vol.38, no.9, pp.95-106, 2017.

[3] W. W. Xing, W. Lu. Exploration and practice of training international software engineering talents. China Higher Education, no. 8, pp. 34-36, 2012.

[4] N. Ye, F. Qi, G. Q. Bian, F. Zhang. Research on the undergraduate education curriculum system of software engineering specialty oriented to the training of international talents. Education Teaching Forum, no. 15, pp.142-143, 2015.

[5] B. B. Zhang. A Study on Cultivating Model of Outstanding Software Engineers' Practice Ability. Master Thesis, Tianjin University, Tianjin, Hebei, China, pp. 14-15, 2013.

[6] W. Lu. Y. Y. Cai, W. W. Xing. Reform and innovation of the international software personnel training mode. Research in Higher Education of Engineering, no. 1, pp. 76-83, 2013.

[7] Y. Q. Zhou, Q. F. Luo, L. J. Huang. Studying on software engineering talents training mode facing ASEAN. Higher Education Forum, no. 11, pp. 15-17, 2011.

[8] Y. Zhang, T. J. Zhao, S. C. Deng. Promote the training of software engineering talents with internationalization. Computer Education, no.15, pp. 9-13, 2015. 